Debreceni Egyetem Fogorvostudományi Kar, Bioanyagtani és Fogpótlástani Tanszék ${ }^{\star}$ Atommagkutató Intézet (ATOMKI), Anyagtudományi Laboratórium, Debrecen**

Semmelweis Egyetem, Gyógyszerésztudományi Kar, Egyetemi Gyógyszertár Gyógyszerügyi Szervezési Intézet, Budapest** Debreceni Egyetem, Természettudományi és Technológia Kar, Fizikai Kémiai Tanszék****

\title{
Polivinil-alkohol (PVA) szál (fiber) alapú szövet (fólia) hidrofilicitásának optimalizálása
}

\author{
DR. CZIBULYA ZSUZSANNA*, DR. CSÍK ATTILA**, DR. BAKÓ JÓZSEF*, \\ DR. NOVÁK LEVENTE*** DR. SZABÓ PÉTER ${ }^{\star \star \star *}$, DR. HEGEDÜS CSABA*
}

\begin{abstract}
A sebgyógyulást elősegítő anyagoknak számos kémiai, biológiai, mechanikai feltételnek kell megfelelniük, mint például a biokompatibilitás, biodegradábilitás; eközben adott ideig meg kell tartaniuk a kialakított szerkezetet, és szelektíven kell kölcsönhatásba lépniük pl. a csontképződésben részt vevő sejtekkel is. Munkánk célja stabil szerkezetet biztosító, hőkezeléssel iniciált, citromsavval keresztkötött polivinil-alkohol vázak elektrosztatikus szálképzéssel történő előállítása volt. A szálak stabilitását a keresztkötőanyag mennyiségének optimalizálásával és a szövetek hőkezelésével kívántuk elérni. A kiindulási polimer oldatok viszkozitását folyásgörbe mérésekből határoztuk meg. Az ebből készített szövetek felületi morfológiáját alacsony vákuumú pásztázó elektronmikroszkópia és nedvesítési peremszög mérésekkel meghatározott paraméterek változásait detektálva tanulmányoztuk. A keresztkötőanyag-tartalom növelése a szálátmérő növekedését, (224 \pm 52 nm-ről, $269 \pm 109$ nm-re) az eloszlás kiszélesedését és a hidrofilicitás csökkenését eredményezte, amely hatásokat a hőkezelés még kifejezettebbé tett. Az ekképpen előállított minták hőkezelés után a desztillált vizes 24-120 órányi áztatásnak is ellenálltak. Az eredmények alapján meghatározható egy felhasználás szempontjából optimális polimer oldat összetétel.
\end{abstract}

Kulcsszavak: Polivinil-alkohol, citromsav, elektrosztatikus szálképzés, hidrofilicitás, nedvesítési peremszög

Rövidítések: PVA = polivinil-alkohol, SEM = pásztázó elektronmikroszkópia

\section{Bevezetés}

Az elektrosztatikus szálképzés (elektrospinning) jól ismert módszer, amely segítségével különböző átmérőjú szálakat, szöveteket lehet készíteni pl. a szövettervezéshez, szabályozott hatóanyag-kibocsátáshoz $[2,19]$. Az elektrospinning során a polimer oldatot egy fém hegyhez csatlakoztatott fecskendőbe töltik, a kivezetésnél kialakul az ún. Taylor-kúp, amelynek alakja a felületi feszültség és az alkalmazott elektrosztatikus viszonyok alakulásától függ. A megfelelő feszültség alkalmazásával a csepp először deformálódik, majd amikor az elektrosztatikus erők meghaladják az oldat felületi feszültségét, szálat képez. A kialakult polimer szál repülés közben, ahogy a töltés a szál közepéből a felszíne felé tart, elveszíti oldószertartalmát. A földelt gyüjtőlemezre (céllemez) így már a száraz polimer szál érkezik meg [1-5, 9-10, 13-14, 21]. Többféle elrendezés létezik, a céllemez lehet sík vagy hengeres felület. A betáplálás tekintetében egy vagy több forrással rendelkező készülék is létezik; például mag-héj szerkezetű szálakat koaxiális rendszerrel állíthatunk elő [11]. Az orvos-biológiai alkalmazásokhoz használható szöveteket különböző ki- indulási polimerekből állíthatjuk elő. Természetes polimerekből, mint például a politejsav, a kollagén vagy a kitozán; illetve szintetikusan elóállított polimerekből, mint a poliglikolsav, poliakrilsav, poliglutamát és az általunk használt polivinil-alkohol (PVA), valamint ezek származékai $[7-9,15,19]$. A PVA [5] biokompatibilis és biodegradábilis anyag. Felhasználható az élelmiszeriparban, gyógyszeriparban, csomagolóiparban és az orvostudományban - pl. a polimervázak rugalmasságának javítására - önállóan vagy biopolimer-keverékek részeként [19]. A feldolgozhatóság szempontjából fontos, hogy a PVA-szálak szerkezeti tulajdonságai az elektrosztatikus szálképzési folyamat paramétereinek optimalizálásával bármilyen moláris tömeggel rendelkező polimer esetén tervezhetőek [10]. A bevonatként is használható polivinil-alkohol szövet legfőbb problémáját a polimerháló jó vízoldhatósága jelenti. Habár az a polimeroldat és az abból készített szövet elóállításakor kifejezetten előnyös, hiszen így az alkalmazott oldószer is biokompatibilis [16]. A szövet felhasználásakor elönytelen a nagymértékű hidrofilicitás, mert a szövet szerkezetének rendkívül rövid idő alatt történő megszűnéséhez vezet [12]. Számos szerkezetmódosítással próbálkoztak 
már a szálak hidrofóbbá alakítására. Ezeket a módosításokat, és a módosítások következtében fellépő, fizikai, reológiai tulajdonságokat, oldhatóságot vízmegtartó képességre gyakorolt hatást foglalják össze egy tanulmányban Jain és mtsai. 2018 [8]. A szerkezetet alkotó polimer választásakor az is fontos, hogy a polimeroldatkészítés és a szövetképzés során használt oldószer mellett az alkalmazott keresztkötő és egyéb adalékanyagok sem lehetnek citotoxikusak [3]. Ezért az alternatív, „zöld” keresztkötő vegyületek, mint az észterkötést kialakító citromsav alkalmazását részesítjük előnyben. [18-20]. A megfelelő hidrofobicitás eléréséhez keresztkötőanyag adagolás mellett hőkezelés alkalmazása is szükséges. A Shi és mtsai. (2015) által alkalmazott $140{ }^{\circ} \mathrm{C}, 2$ órás hőkezelés helyett az alacsonyabb $120{ }^{\circ} \mathrm{C}$-os hőkezelés hosszabb ideig való alkalmazása is megfelelő lehet $[13,18]$. Jelen munka célja olyan mesterséges, biokompatibilis, biodegradábilis és optimalizált hidrofilicitású szövet előállítása volt, mely megfelelő ideig megtartja a szerkezetét, majd toxikus maradék nélkül lebomlik, így alkalmas lehet fogászati szövettervezési feladatokra.

\section{Anyagok és módszerek}

Felhasznált anyagok, polimeroldatok készítése A kísérleteinkhez gyógyszer-segédanyag minőségű polivinilalkoholt használtunk. (Polyvinyl alcohol 18-88, Merck, hidrolízis foka (USP) 85-89\% közötti, a moláris tömegét gél permeációs - méretkizárásos kromatográfiával meghatározva (Agilent Technologies 1260 Infinity II típusú kromatográf, Phenomenex PolySep GFC-P linear, elválasztási tartomány 1kD-10 MDa, Kalifornia, Amerikai Egyesült Államok) a tömeg szerinti molekulatömeg átlagértéke 65000 körülinek, a polidiszperzitás foka 3,168-nak bizonyult. A szálképzéshez használt keverékhez $10 \mathrm{~m} / \mathrm{m} \%$-os PVA polimeroldatot feloldódásig $80{ }^{\circ} \mathrm{C}$-on való keverés közben duzzasztottuk.

\section{Polimeroldatok viszkozitásának meghatározása}

A polimeroldat keverékek viszkozitását $25^{\circ} \mathrm{C}$-on MCR 102 Reométer, (Anton Paar GmbH, Ausztria) 50 mm-es lap-lap geometriáiú mérőfejjel mértük, növekvő, majd csökkenő sebesség gradienst beállítva. A határviszkozitást a csökkenő sebesség gradiens mellett mért folyásgörbére illesztett Bingham-féle egyenlet $\mathrm{T}=\mathrm{TB}+\eta \mathrm{pl}(\mathrm{d} / \mathrm{dt}$ ) alapján határoztuk meg. (Ahol t a nyírófeszültség, TB a Binghamféle folyáshatár és npl a határviszkozitás.)

\section{Elektrosztatikus szálképzés}

A szálakat Nanospinner NS1 (Inovenso Ltd, Törökország) készülékkel állítottuk elő. Az áramlási sebesség $0,75 \mathrm{ml} /$ óra volt (Alaris GH infúziós pumpa). Az oldatokat egy 5 ml-es fecskendőbe töltöttük, melyhez egy polietilén cső segítségével csatlakoztattunk egy Sterican injekciós tüt. A szálakat egy $15 \mathrm{~cm}$-es távolságra elhelyezett $15 \times 15 \mathrm{~cm}$ felületű alumíniumfóliával fedett földelt kollektor lapon gyűjtöttük 30 percen keresztül. Az alkalmazott feszültség $23 \mathrm{kV}$ volt. A korábbi kísérleti eredményeinket is figyelembe véve a Shi és mtsai. [18] által alkalmazott $140{ }^{\circ} \mathrm{C}, 2$ órás hőkezelést, $120^{\circ} \mathrm{C}$ 4 órásra módosítottuk, és az általuk alkalmazott citromsav mennyiségét megnöveltük.

\section{Pásztázó elektronmikroszkópos (SEM) vizsgálat}

Az előállított szövetek felületi morfológiáját alacsony vákuumú pásztázó elektronmikroszkóppal vizsgáltuk (LV-SEM, JEOL IT500HR, Tokyo, Japan). A töltés felhalmozódás elkerülése érdekében a szigetelő minták vizsgálata alacsony gyorsító feszültségen (3 kV) és nyomáson (30 Pa) történt.

\section{Nedvesítési peremszög meghatározás}

A vízcseppek által a szöveteken mutatott nedvesítési peremszög (1. kép) értékeket Krüss Drop Shape analyzer DSA 30 Drop Shape Analyzer (Krüss GmbH, Hamburg, Németország) segítségével, Young Laplace modellt alkalmazva határoztuk meg. A nedvesítési peremszög eredményeket Huang és mtsai. által meghatározott értékekhez hasonlóan [6], azonos mérési időpontot kiválasztva, a csepp felületre érkezése után azonnal leolvastuk, figyelembe véve hogy a hidrofilicitásuk és a natív szálak különböző mértékű oldódása miatt a mért értékek csak néhány mérés erejéig állandók. Ugyanezen okból a szövet vastagságával változik a mért paraméter is, így csak a nedvesítési peremszög-értékek változásaiból adódott irányvonalat elemeztük.

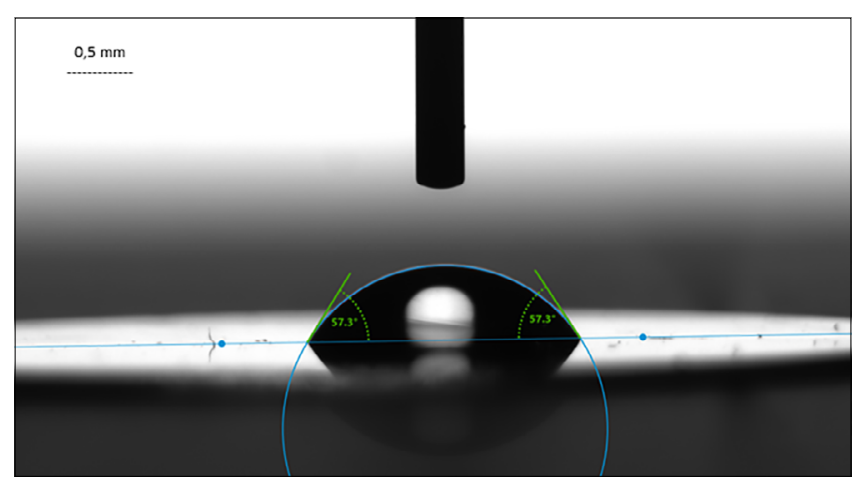

1. kép: Példa a nedvesítési peremszög meghatározásának menetére

\section{Szálátmérö-meghatározás}

A szálvastagságok meghatározása nyílt forráskódú ImageJ (National Institutes of Health, Amerikai Egyesült Államok) program segítségével történt. A megfelelő eredmények érdekében mintánként 100 szál adatait határoztuk meg, az Image J szoftverből leolvasott értékekből Excel program segítségével hisztogramokat készítettünk, az eredményeket OriginPro (OriginLab, Amerikai Egyesült Államok) programban ábrázoltuk. 


\section{Eredmények}

Minták összetétele, viszkozitása

Az 1. táblázatban feltüntetett összetételü mintákat vizsgáltuk. A minták készítése során az adagolt PVA-oldat ( $10 \mathrm{~m} / \mathrm{m} \%$-os) mennyiségét állandó értéken tartva növeltük a citromsav koncentrációját. (Az oldatok $\mathrm{pH}$-ja 6-ról 2-re csökkent a legmagasabb citromsavtartalom hozzáadása után.) A bemutatott minták összetételét és viszkozitását tartalmazza az 1. táblázat.

1. táblázat

Mintaösszetétel és a keverék viszkozitása

\begin{tabular}{|c|c|c|c|}
\hline minta & $\mathrm{c}_{\text {PVA }}, \mathrm{g} / 100 \mathrm{~g}$ & $\mathrm{c}_{\text {citromsav }}, \mathrm{g} / 100 \mathrm{~g}$ & $\mu_{\mathrm{pl}}, \mathrm{mPas}$ \\
\hline PVA & 10,00 & 0,00 & 410,31 \\
\hline A & 9,79 & 2,13 & 494,66 \\
\hline B & 9,58 & 4,17 & 510,18 \\
\hline C & 9,39 & 6,08 & 489,78 \\
\hline D & 9,20 & 8,00 & 475,55 \\
\hline E & 8,99 & 10,07 & 489,95 \\
\hline F & 8,82 & 11,76 & 485,04 \\
\hline
\end{tabular}

A polimeroldatok viszkozitása $9,58 \mathrm{~g} / 100 \mathrm{~g}$ citromsavtartalomig növekedett a keresztkötő anyagként használt citromsav mennyiségének növelésével, ezután csökkenést mutatott. Az így elkészült keverékekből elektroszálképzéssel szöveteket állítottunk elő. Erre mutat egy példát a 2. kép.

Az általunk összeállított rendszerek esetén a Shi és munkatársai által leírt $140^{\circ} \mathrm{C}, 2$ órányi illetve az alacsonyabb $120^{\circ} \mathrm{C}$ [13], 4 órányi hökezelés hatására hidrofil/ hidrofób jellegben kialakuló eltéréseket kívántuk összevetni a natív, hőkezelésmentes minták esetében mérhető nedvesítési peremszögértékekkel. (3. kép)

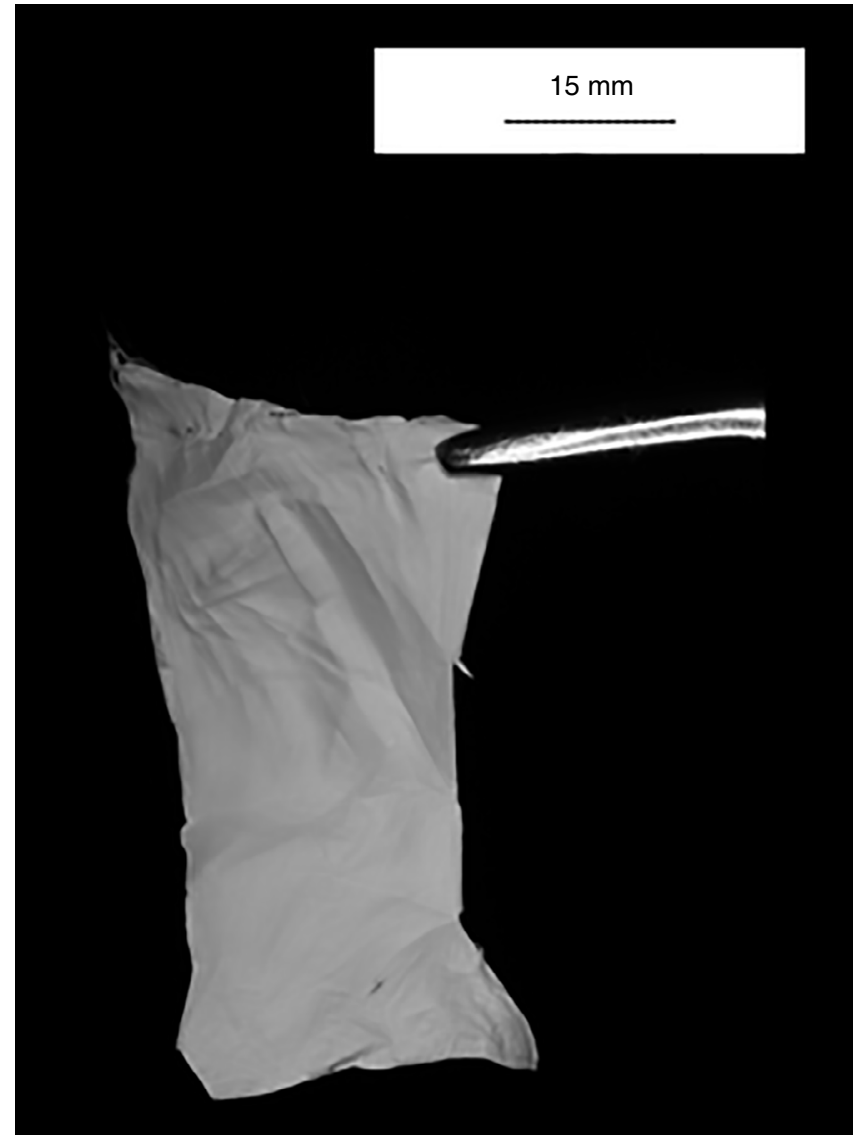

2. kép: Elektroszálképzéssel előállított PVA-alapú szövet

A 3. képen a hőkezelés előtti (PVA natív) minták azonos időpontban leolvasott nedvesítési peremszög értékeinek összehasonlítása látható a $120^{\circ} \mathrm{C}$-on, 4 órán és $140^{\circ} \mathrm{C}$-on 2 órán keresztüli hőkezelt minták paramétereivel. A mért nedvesítési peremszögértékek minden esetben telítésbe futnak a citromsavtartalom növelésével. A natív minták $10 \mathrm{~m} / \mathrm{m} \%$ citromsav-tartalom értéken érik el a maximális hidrofobicitást $\left(P V A_{\text {nat }}\right.$ $-10 \mathrm{~m} / \mathrm{m} \%$ Citr $_{\text {nat }}$ ), melyet a hőkezelés az alacsonyabb koncentrációk irányába tol el. A telítési értékek alatt, függetlenül a hőkezelés mértékétől, nem tapasztaltunk szignifikáns változást, míg az azokat meghaladó értékek esetében nem szignifikáns a növekedés. A hidrofobicitás növekedését a hőkezelés még kifejezettebbé teszi, amit

3. kép: A nedvesítési peremszögek növekedő citromsavmennyiségeket tartalmazó minták esetében (Az egyes koncentrációkhoz tartozó oszlopok sorrendben a natív, a $120^{\circ} \mathrm{C}$-on 4 órán át hőkezelt valamint a $140^{\circ} \mathrm{C}$-on 2 órán át hőkezelt mintákra vonatkoznak.) 
a felületi $\mathrm{OH}$-csoportok lekötésével magyarázhatjuk. A 2. táblázatból az is látható, hogy a különböző hőmérsékletű kezelések is szignifikáns eltérést okoznak az azonos összetételű minták nedvesítési peremszögértékeiben $\left(2 \mathrm{~m} / \mathrm{m} \%\right.$ natív $-2 \mathrm{~m} / \mathrm{m} \% 120^{\circ} \mathrm{C}, 2 \mathrm{~m} / \mathrm{m} \%$ $120^{\circ} \mathrm{C}-2 \mathrm{~m} / \mathrm{m} \% 140{ }^{\circ} \mathrm{C}$ ). A $120^{\circ} \mathrm{C}$, 4 órányi hőkezelés szignifikánsan magasabb hidrofobicitást okoz a $140^{\circ} \mathrm{C}$, 2 órányi hőkezeléshez képest, amint ez már a $2 \mathrm{~m} / \mathrm{m} \%$-os citromsav hozzáadása után is kifejeződött; így a további hőkezelt mintaként hivatkozott eredmények, a $120^{\circ} \mathrm{C}$-on 2 órán keresztül hőkezelt mintákra vonatkoznak.

2. táblázat

Változások szignifikancia értékei

\begin{tabular}{|l|l|}
\hline $\begin{array}{l}\text { Telítési maximum elérése } \\
\text { az egyes sorozatokon belül }\end{array}$ & $\mathrm{P}(\mathrm{T}<=\mathrm{t})$ \\
\hline $\begin{array}{l}\text { Natív minták: } \\
\mathrm{PVA}_{\text {nat }}-10 \% \text { Citr }\end{array}$ & 0,018971 \\
\hline $\begin{array}{l}120{ }^{\circ} \mathrm{C}-\text { on hőkezelt minták: } \\
\mathrm{PVA} 120^{\circ} \mathrm{C}-2 \% 120^{\circ} \mathrm{C}\end{array}$ & 0,000012 \\
\hline $\begin{array}{l}140{ }^{\circ} \mathrm{C}-\text { on hőkezelt minták: } \\
4 \% \text { Citr } 140{ }^{\circ} \mathrm{C}-6 \% \text { Citr } 140{ }^{\circ} \mathrm{C}\end{array}$ & 0,022159 \\
\hline Különböző hőmérsékletú hőkezelés hatása & \\
\hline $2 \%$ natív-2\% $120^{\circ} \mathrm{C}$ & 0,000139 \\
\hline $2 \% 120^{\circ} \mathrm{C}-2 \% 140^{\circ} \mathrm{C}$ & 0,000001 \\
\hline
\end{tabular}

A citromsavat is tartalmazó minták (A-től F)-ig esetén látható (4.a kép, 4.b kép), hogy a hőkezelés hatására a szövet súrüsége csökken, a citromsavmentes PVA esetén nem tapasztalható változás. Az alkalmazott beállítások mellett az $\mathrm{E}$, valamint az $\mathrm{F}$ minta esetén a jelenlevő citromsavfelesleg a SEM-mérések közben valószínúleg a kis területre fókuszált pásztázó elektronnyaláb okozta lokális melegedés a vákuumkamrában mért nyomásérték változásából következtetve $\mathrm{CO}_{2}$ kibocsátást eredményezett, így ezek a minták kisebb ( $\mathrm{F}$ natív minta 3000x-es, D és $E$ hőkezelt minta: $4500 x-o s$, $F$ hőkezelt minta 1000x-es) nagyításban kerültek bemutatásra. A natív minták esetén az eloszlásgörbe szélessége és a maximum szálátmérő-értékek is növekedést mutatnak, míg hőkezelés hatására citromsav jelenlétében az eloszlásgörbéken megjelenik egy másodlagos maximumérték is. Az ImageJ szoftverrel meghatározott szálátmérő maximumok értékeit és az átlagos szálátmérőket tartalmazza a következő két kép. (5.a kép, 5.b kép)

$\mathrm{Az}$ 5.a képen látható, hogy a citromsav mennyiségének növelése növekedő trendet mutat a natív minták átlagos szálátmérőinek változásában. A SEM-képeken látható, hogy a szálvastagság növekedésével a szálak rendezettsége is csökken, a citromsavtartalom növekedésével egyre inkább ívelt szerkezetet mutatnak. A szálátmérők eloszlásgörbéje (4.a kép, 4.b kép), amint azt az 5.a, b képen látható hibahatárok növekedése is mutatja, fokozatosan kiszélesedik. $12 \mathrm{~m} / \mathrm{m} \%$-os citromsavtartalomnál megháromszorozódik az elsődleges szálátmérő, de az eloszlásgörbe jelentősen ellaposodik. Meg kell hát találni az optimális citromsavtartalom értéket, ami a felhasználás szempontjából megfelelő szálátmérőméretet és -eloszlást adja. Hőkezelés hatására (5.b kép) a szálátmérők növekedése kifejezettebbé válik, az eloszlásgörbék kiszélesedése mellett minden esetben megjelenik egy másodlagos maximum is (a képen csak az elsődleges maximum értékeket tüntettük fel).

A hidrofil/hidrofób tulajdonságok hőkezelés-változását a mindkét kezelési hőmérsékleten hasonló nedvesítési peremszögértéket mutató $D$ jelú $(8 \mathrm{~m} / \mathrm{m} \%$ citromsav tartalmú) minta esetén vizsgáltuk. Mivel 6 százalékos citromsavtartalom felett a két különböző hőmérsékleten való hőkezelés hasonló mértékủ hidrofobicitást eredményezett, a hőkezelés, valamint 1 és 5 napos desztillált vízben való áztatás hatását a $D$ jelü minta esetén $120^{\circ} \mathrm{C}$-on 2 órán át hőkezelt mintákra vonatkozóan mutatjuk be (6. kép, 3. táblázat).

Ha a 6. képet összehasonlítjuk a 4.a, b kép D mintára vonatkozó képeivel, elmondhatjuk, hogy a $8 \mathrm{~m} / \mathrm{m} \%$ citromsavat tartalmazó minta hőkezelés előtt még sürü szövetet ad. Ez $120^{\circ} \mathrm{C}, 2$ óra hőkezelés után ritkábbá válik, majd 1 napi desztillált vízben áztatás, levegőn való szárítás után a szövet szerkezete részben bomlik, a szálak vízben megduzzadnak, és a felvett vizet magukban is tartják. Így ismét sürü, de hajlított szálszerkezetű szövet alakul ki.

A nedvesítési peremszögértékeket (3. táblázat) is figyelembe véve elmondható, hogy a minta rövid idejú áztatásának hatására a szövet felszíne hidrofilebbé válik. A hőkezelt mintára meghatározott $68^{\circ}$-os értékről, 1 napos vizes áztatás hatására $52^{\circ}$-ra csökken a nedvesítési peremszög értéke. A minta szerkezete 5 napos áztatás hatására a rövidebb idejű áztatást követően jellemzőhöz képest látszólag nem változik, de a mérhető nedvesítési peremszögértéke visszatér az eredetileg hőkezelt mintára jellemző érték közelébe, $65^{\circ}$-ra. Az ImageJ szoftver által meghatározott szálátmérők a fentebbi táblázatnak megfelelően változnak. Az átlagos szálátmérők a natív mintához képest növekedést mutatnak mind a hőkezelés, mind a desztillált víz hatására bekövetkező duzzadás hatására. Látható, hogy az áztatás időtartama 5 napos időintervallumon belül nem befolyásolja jelentősen a szálátmérőket, tehát a szerkezet vizes áztatás közben is stabil marad.

\section{Megbeszélés}

A PVA-szövet biokompatibilis és kellöen rugalmas szerkezetet ad, de az alkalmazás során gondot jelenthet annak túlzott vízoldhatósága. A szövet hidrofóbbá tétele többféleképpen történhet. Ilyen például a szálak különböző keresztkötő anyagokkal pl. glutáraldehiddel, mely már nyomokban elóforduló mennyiségben is citotoxititást mutat, való kezelése [5]. Egy másik lehetőség, amikor a keresztkötő anyagot eleve bejuttatjuk a rendszerbe, majd a spinningelést magas höfokon való hőkezelés követi. Ezek egy alternatívája olyan karboxil cso- 

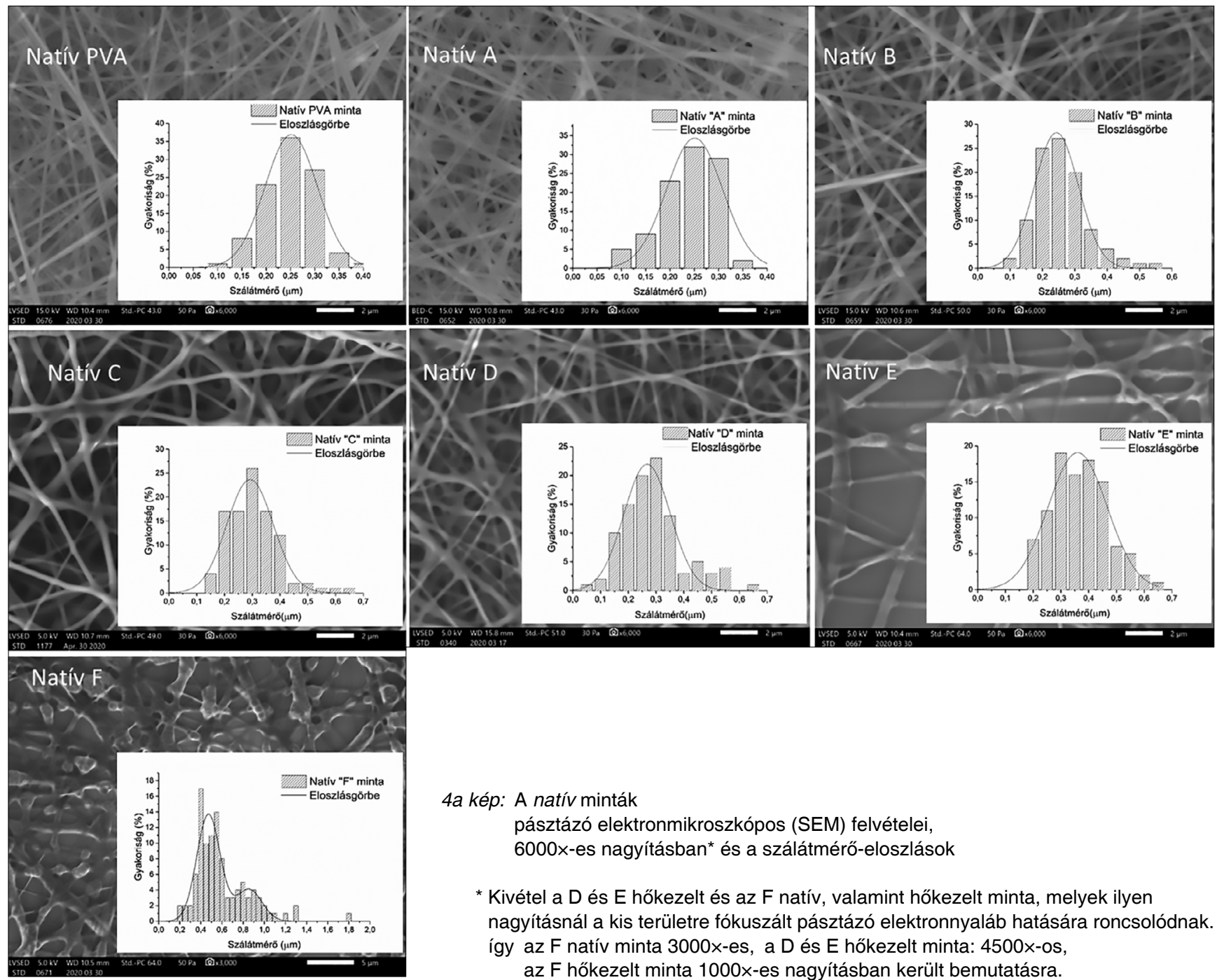

4a kép: A natív minták

pásztázó elektronmikroszkópos (SEM) felvételei,

6000x-es nagyításban* és a szálátmérő-eloszlások

* Kivétel a $D$ és $E$ hőkezelt és az $F$ natív, valamint hőkezelt minta, melyek ilyen nagyításnál a kis területre fókuszált pásztázó elektronnyaláb hatására roncsolódnak.

így az $\mathrm{F}$ natív minta $3000 x$-es, a $\mathrm{D}$ és $\mathrm{E}$ hőkezelt minta: 4500x-os, az F hőkezelt minta 1000x-es nagyításban került bemutatásra.

portokat tartalmazó vegyületek alkalmazása [9], melyek viszonylag rövid ideig tartó, és alacsonyabb hőmérsékleten történő hőkezelés hatására is elősegítik a keresztkötések kialakulását. A szakirodalomban az általunk választott citromsav alkalmazására is található néhány biztató kutatási eredmény. Pangon és mtsai az általuk használt biopolimer oldódását, majd PVA-val történő keresztkötések kialakulását segítette elő különböző karboxil-csoport tartalmú anyagokkal, többek között citromsavval [13]. Sabzi és mtsai PVA hidrogélek keresztkötésére használtak különböző mennyiségben (10, 20, $30 \mathrm{~m} / \mathrm{m} \%$ ) citromsav oldatokat [17]. Shi és mtsai. 2015-ben
0,16-0,64 m/m\% közötti mennyiségben alkalmazták a citromsavat PVA-szálak keresztkötő anyagaként. [18]. A kisebb citromsavtartalmú mintáikat $140^{\circ} \mathrm{C}$-on 2 órán át hőkezelték, így sikerült olyan szövetet előállítaniuk, melynek morfológiája 24 órányi vizes áztatás hatására csak kismértékben változott. Ezeket figyelembe véve kívántunk egy olyan szövetet előállítani, mely vizes közegben egy hétig bizonyíthatóan megtartja a megfelelő szerkezetét.

A minták készítésénél figyelembe kellett venni, hogy az általunk használt PVA mérete és molekulatömege nem azonos a Shi és mtsai által használttal [18]. Ameny-

\section{3. táblázat}

A hökezelés, majd az azt követő desztillált vízben áztatás hatása a szálátmérö átlagértékeire ( $\left.d_{\text {átlag}}\right)$, natív (N), hőkezelt (HK) hökezelés után 24 órán át desztillált vízben áztatott $(H K+24 h)$ 120 órán át desztillált vízben áztatott (HK $+120 h) 8$ m/m\%-os citromsav tartalmú (D jelü minta) PVA-szövet esetén

\begin{tabular}{|l|c|c|c|c|c|}
\hline Minta & $\mathrm{c}_{\text {citr. }}, \mathrm{g} / 100 \mathrm{~g}$ & $\mathrm{~d}_{\text {átlag’N}, \mu \mathrm{m}}$ & $\mathrm{d}_{\text {átlag HK}}, \mu \mathrm{m}$ & $\mathrm{d}_{\text {átlag HK}},+24 \mathrm{~h}$ d.víz, $\mu \mathrm{m}$ & $\mathrm{d}_{\text {átlag, HK }}+120 \mathrm{~h}$ d.víz, $\mu \mathrm{m}$ \\
\hline D & 8,00 & $0,27 \pm 0,11$ & $0,47 \pm 0,18$ & $0,57 \pm 0,22$ & $0,58 \pm 0,24$ \\
\hline
\end{tabular}



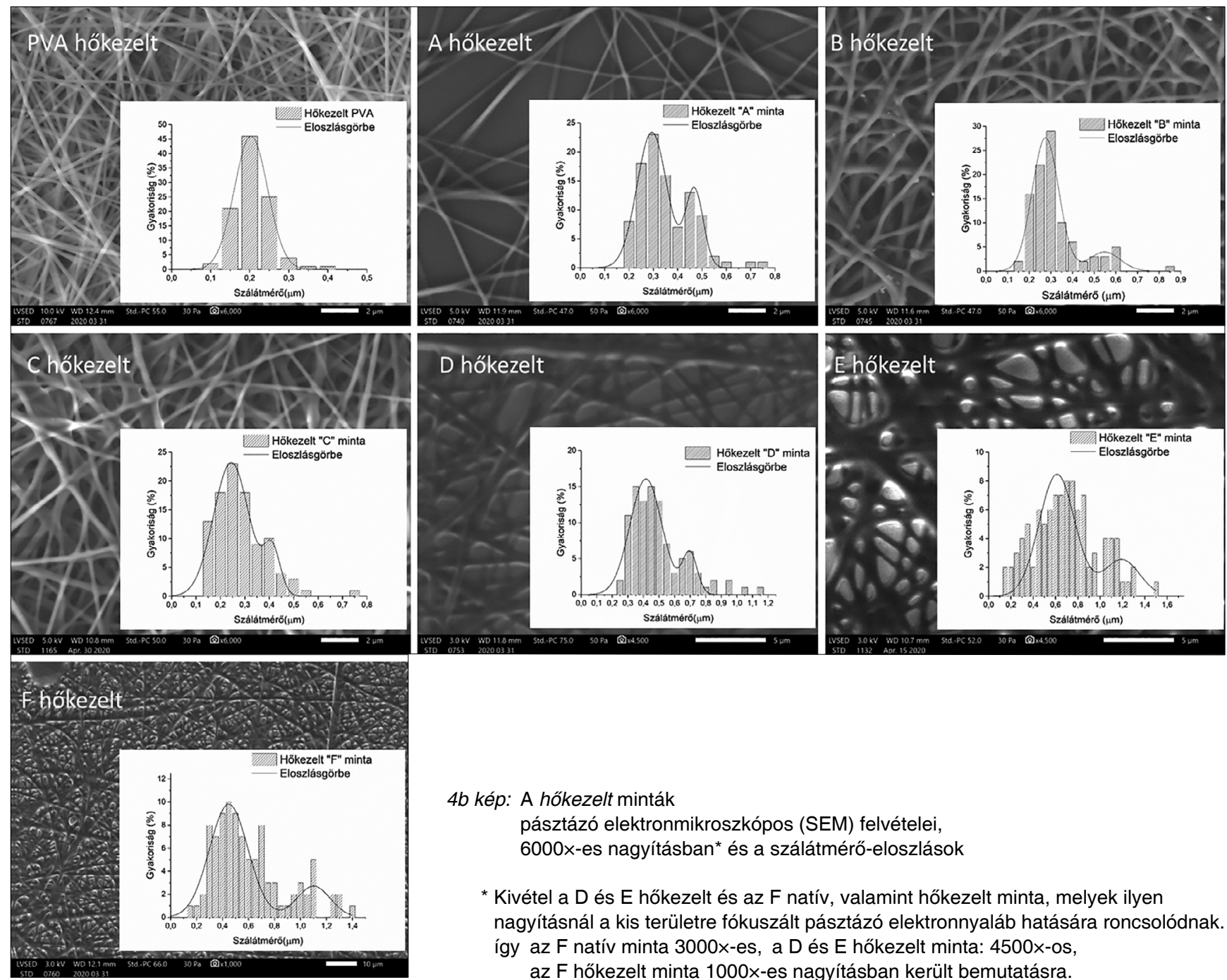

4b kép: A hőkezelt minták

pásztázó elektronmikroszkópos (SEM) felvételei,

6000x-es nagyításban* és a szálátmérő-eloszlások

* Kivétel a D és $E$ hőkezelt és az F natív, valamint hőkezelt minta, melyek ilyen nagyításnál a kis területre fókuszált pásztázó elektronnyaláb hatására roncsolódnak. így az F natív minta $3000 x$-es, a D és $E$ hőkezelt minta: $4500 x$-os, az F hőkezelt minta 1000x-es nagyításban került bemutatásra.
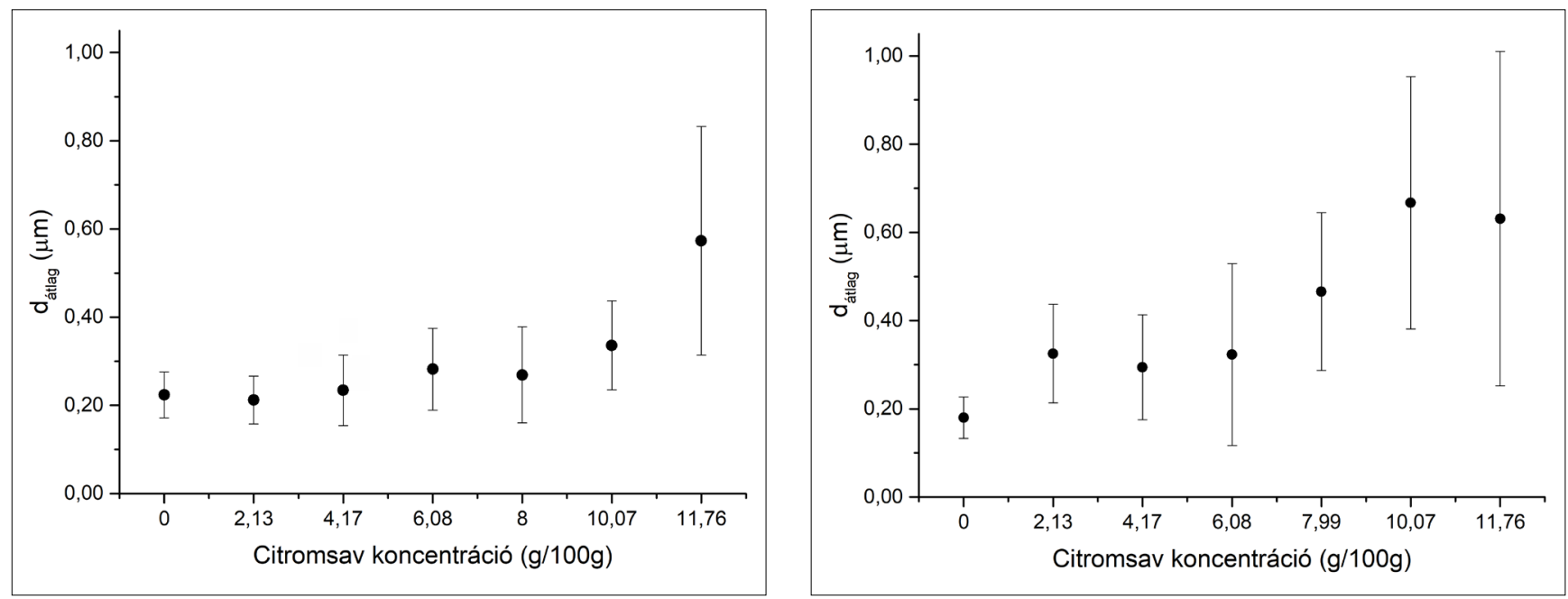

5. a, b. kép: A natív (a) és hőkezelt (b) minták szálátmérőinek változását bemutató ábra, növekedő citromsav-mennyiségeket tartalmazó minták esetében 

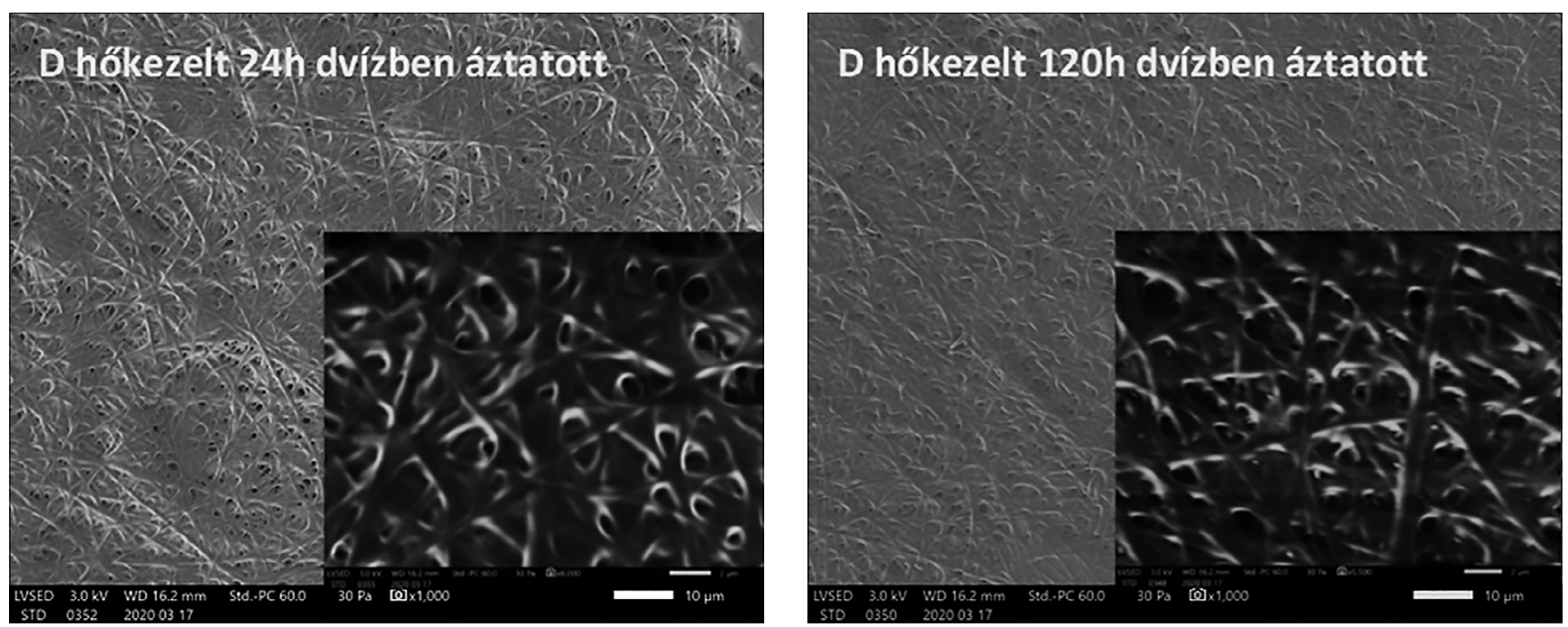

6 kép: A 8 m/m\% citromsavat tartalmazó PVA-minta hőkezelést követő 24 ,

illetve 120 órás desztillált vízben való áztatás utáni szerkezetvizsgálatára vonatkozó pásztázó elektronmikroszkópos (SEM) felvételei (1000x-es és 6000x-es nagyításban)

nyiben a későbbiekben biopolimereket, vagy szerves hatóanyagot kívánunk bevinni a szerkezetbe, a 140 fokos hőkezelés túl magas lehet, hiszen a biopolimertartalmú minták szerkezete ezen a hőmérsékleten nagy valószínűséggel sérül. Ennek alapján két változtatási irány volt lehetséges. Az egyik a hőmérséklet csökkentése és a hőkezelés idejének megnövelése [13]; a másik a keresztkötő anyag mennyiségének növelése. A polimeroldatokra meghatározott viszkozitás-értékeink 9,58 g/100 g citromsavtartalomig növekedtek a keresztkötő anyagként használt citromsav mennyiségének növelésével, majd csökkentek. (Amint az az 1. táblázatban látható.) Valószínúsíthető, hogy a citromsav menynyiségének túlzott növelése, már nem segíti elő az észteresedési folyamatot, a keresztkötési pontok kialakulását, mindösszesen megnöveli a rendszerben megjelenő szabad karboxil-csoportok számát. A növekvő citromsavmennyiség és az ezzel együtt járó csökkenő $\mathrm{pH}$ hatására csökken a duzzadás mértéke is (6-ról 2 körüli értékre) [17], ami szintén hozzájárulhat a viszkozitás állandósulásához. A natív minták szálátmérőértékeiben körülbelül 20-24 százalékos növekedést tapasztaltunk.

A szöveti felület hidrofil/hidrofób tulajdonságainak változása nedvesítési peremszögmérésekkel nyomon követhető. Amint az 3. ábrán is bemutatásra került a különböző citromsavtartalmú szövetek esetén a keresztkötő anyag mennyisége különbözőképpen hat a vízzel adott nedvesítési peremszög értékekre. A citromsavtartalom növelése kezdetben hidrofóbbá teszi a szövetet, majd a görbe felfutása telítést mutat. Ez várható is volt, hiszen a citromsav karboxil-csoportokat tartalmaz, így észterkötéseken keresztül leköti a PVA OH-csoportjainak egy részét, viszont feleslegben hozzáadott citromsav hatására a keresztkötések száma már nem képes növekedni. Az előállított rendszerek még így is hidrofil tulajdonságokat mutatnak, hiszen a nedvesítési peremszög minden esetben $90^{\circ}$ alatti érték. Hőkezelés hatására a felületi $\mathrm{OH}$-csoportok egy része is megszünik [20]. Elmondható, hogy a keresztkötő anyag mennyiségének növelésével egyre vastagabb szálakból álló szövetet állíthatunk elő, de egyre kevésbé lehet szűk tartományra korlátozni a szálátmérő-eloszlást.

Hőkezelés hatására kialakulnak a keresztkötések, amit már megnövekedett nedvesítési peremszögértékek is mutattak. (Amint az a 3. ábrán is látható.) A szövetek sűrüsége csökken, a szálak még inkább íveltté válnak. Az átlagos szálátmérők a $120{ }^{\circ} \mathrm{C}$-os hőkezelés hatására körülbelül 10-50\%-os növekedést mutatnak, a szálátmérő-maximumok is hasonlóan változnak. Hőkezelés után, már körülbelül $9 \mathrm{~m} / \mathrm{m} \%$-os citromsavtartalom esetén elérjük a natív mintáknál meghatározott maximális átlagos szálátmérőértéket. 24, 120 órányi vizes áztatás után bizonyítottuk a hőkezelt szövetek stabilitását. Habár a szálátmérők a vízben való duzzadás következtében kezdetben növekedést mutatnak, de ezt a többnapos áztatás nem módosítja.

További mérések szükségesek e rendszerek degradábilitásának, toxicitásának, hatóanyaggal tölthetőségének meghatározásához, mely lehetővé teszi e különleges tulajdonságú anyagok fogászati alkalmazását is.

\section{Következtések}

A citromsavadagolás következtében a szövetek átlagos szálátmérője egyértelmű növekedést mutat. $A 2 \mathrm{~m} / \mathrm{m} \%$ feletti citromsavmennyiség adagolása esetén a szövet hidrofobicitása növekedést mutat. A hőkezelt minták esetén kimutatható, hogy körülbelül $9 \mathrm{~m} / \mathrm{m} \%$-os citromsavadagolás hatására elérhető a natív mintáknál meghatározott maximális átlagos szálátmérőérték. En- 
nél több keresztkötő anyag jelenléte, valamint a hökezelés együttes hatása a minták szerkezetének sérüléséhez vezet. Az eredmények alapján elmondható, hogy sikerült optimalizálni a fogászati alkalmazások alapjául szolgáló szövetek hidrofilicitását.

\section{Köszönetnyilvánítás}

A publikáció elkészítését a GINOP-[2.3.2-15-2016-00022] számú projekt támogatta. A projekt az Európai Unió támogatásával, az Európai Regionális Fejlesztési Alap társfinanszírozásával valósult meg.

A tanulmány alapjául szolgáló kutatást a Tématerületi Kiválósági Program 2020 (TKP2020-IKA-04) támogatta a Biotechnológia Tématerület keretében, a Nemzeti Kutatási, Fejlesztési és Innovációs Alap (NKFI Alap) finanszírozásában.

A mikroszkópos vizsgálatok elkészítését a GINOP2.3.2-15-2016-00029 számú projekt támogatta. A projekt az Európai Unió támogatásával, az Európai Regionális Fejlesztési Alap társfinanszírozásával valósult meg.

\section{Irodalom}

1. Baghaban-Eslaminejad M, Oryan A, Kamali A, Moshiri A: Chapter 25 - The role of nanomedicine, nanotechnology, and nanostructures on oral bone healing, modeling, and remodeling. Nanostructures for Oral Medicine. Elsevier 2017; 777-832. https://doi.org/10.1016/B978-0-323-47720-8.00026-2

2. Bottino MC, Thomas V, Janowski GM: A novel spatially designed and functionally graded electrospun membrane for periodontal regeneration. Acta Biomater 2011; 7 (1): 216-224. https://doi.org/10.1016/j.actbio.2010.08.019

3. Cheng J, JuN Y, QIN J, LeE SH: Electrospinning versus microfluidic spinning of functional fibers for biomedical applications. Vol. 114, Biomaterials Elsevier Ltd. 2017; 121-143. https://doi.org/10.1016/j.biomaterials.2016.10.040

4. Deneke N, Dohadwala S, Moore Q, Nave F, Thompson A: Evaluating alternative crosslinking agents in poly(vinyl alcohol) hydrogels membranes. 2018; 63-81.

5. Gough JE, SCOTCHFORd CA, DownEs S: Cytotoxicity of glutaraldehyde crosslinked collagen/poly(vinyl alcohol) films is by the mechanism of apoptosis. J Biomed Mater Res 2002; 61 (1): 121-130. https://doi.org/10.1002/jbm.10145

6. Huang F, WeI $Q, C_{A I} Y$, Wu N: Surface structures and contact angles of electrospun poly(vinylidene fluoride) nanofiber membranes. Int J Polym Anal Charact 2008; 13 (4): 292-301. https://doi.org/10.1080/10236660802190963

7. Ivanovski S, Vaquette C, Gronthos S, Hutmacher DW, Bartold PM: Multiphasic scaffolds for periodontal tissue engineering. Journal of Dental Research SAGE Publications Inc. 2014; 1212-1221. https://doi.org/10.1177/0022034514544301
8. JaIN N, Singh VK, Chauhan S: A review on mechanical and water absorption properties of polyvinyl alcohol based composites/films. Journal of the Mechanical Behavior of Materials Walter de Gruyter GmbH 2017; 213-222. https://doi.org/10.1515/jmbm-2017-0027

9. JANG JH, CASTANO O, KIM HW: Electrospun materials as potential platforms for bone tissue engineering. Vol. 61, Advanced Drug Delivery Reviews 2009; 1065-1083. https://doi.org/10.1016/j.addr.2009.07.008

10. KOSKI A, YIM K, SHIVKUMAR S: Effect of molecular weight on fibrous PVA produced by electrospinning.

Mater Lett. 2004; 58 (3-4): 493-497. https://doi.org/10.1016/S0167-577X(03)00532-9

11. LI F, ZHAO Y, SONG Y: Nanofibers. InTech 2010; 419-438.

12. Meneghello G, Parker DJ, Ainsworth BJ, Perera SP, Chaudhuri JB, Ellis MJ, et al: Fabrication and characterization of poly(lactic-co-glycolic acid)/polyvinyl alcohol blended hollow fibre membranes for tissue engineering applications.

J Memb Sci 2009; 344 (1-2): 55-61. https://doi.org/10.1016/j.memsci.2009.07.034

13. Pangon A, Saesoo S, Saengkrit N, Ruktanonchai U, Intasanta V: Multicarboxylic acids as environment-friendly solvents and in situ crosslinkers for chitosan/PVA nanofibers with tunable physicochemical properties and biocompatibility.

Carbohydr Polym 2016; 138: 156-165. https://doi.org/10.1016/j.carbpol.2015.11.039

14. Pelipenko J, Kocbek P, Kristl J: Critical attributes of nanofibers: Preparation, drug loading, and tissue regeneration. Vol. 484, International Journal of Pharmaceutics Elsevier 2015; 57-74. https://doi.org/10.1016/j.ijpharm.2015.02.043

15. Pilipchuk SP, Plonka AB, Monje A, Taut AD, Lanis A, Kang B, et al: Tissue engineering for bone regeneration and osseointegration in the oral cavity. Dent Mater 2015; 31 (4): 317-338. https://doi.org/10.1016/j.dental.2015.01.006

16. RWEI SP, HuANG CC: Electrospinning PVA solution-rheology and morphology analyses. Fibers Polym 2012; 13 (1): 44-50. https://doi.org/10.1007/s12221-012-0044-9

17. Sabzi M, Afshari MJ, Babaahmad M, Shafagh N: $\mathrm{pH}$-dependent swelling and antibiotic release from citric acid crosslinked poly(vinyl alcohol) (PVA)/nano silver hydrogels. Colloids Surfaces B Biointerfaces 2020; 188: 110757-110767. https://doi.org/10.1016/j.colsurfb.2019.110757

18. SHI J, YANG E: Green electrospinning and crosslinking of polyvinyl alcohol/citric acid. J Nano Res 2015; 32: 32-42. https://doi.org/10.4028/www.scientific.net/JNanoR.32.32

19. Soares RMD, Siqueira NM, Prabhakaram MP, Ramakrishna S: Electrospinning and electrospray of bio-based and natural polymers for biomaterials development. Vol. 92, Materials Science and Engineering C. Elsevier Ltd. 2018; 969-982. https://doi.org/10.1016/j.msec.2018.08.004

20. Sonker AK, Teotia AK, Kumar A, Nagarale RK, Verma V: Development of Polyvinyl Alcohol Based High Strength Biocompatible Composite Films. Macromol Chem Phys 2017; 218 (15): 1700130-1700143. https://doi.org/10.1002/macp.201700130

21. Voniatis C, Balsevicius L, Barczikai D, Juriga D, TaKács $A$ KöHIDAI L, et al: Co-electrospun polysuccinimide/poly(vinyl alcohol) composite meshes for tissue engineering. J Mol Liq 2020; 306: 112895-112903. https://doi.org/10.1016/j.molliq.2020.112895 


\author{
Czibulya Zs, Csík A, Bakó J, Novák L, Szabó P, Hegedüs Cs
}

\title{
The optimization of hydrophilicity of PVA scaffold due to citric acid addition and heat treatment
}

Materials developed for wound healing have to meet several criteria, such as being non-cytotoxic, biocompatible, biodegradable, having good mechanical properties, and acting selectively with osteoblasts. The aim of this study was, using an electrospinning method, to prepare a polymer scaffold to get a stable, adequate, hydrophilic structure, which will enhance wound healing during bone regeneration. To achieve that, a cross-linked polyvinyl alcohol fibre net was prepared by heat treatment and applied to the water-based polymer in presence of a citric acid solution. The viscosity of the initial polymer was determined from the flow curve measurements. The surface properties of the fibre nets were monitored by the low-vacuum scanning electron microscopy and the contact angle measurements. It was found that the addition of a citric acid as a cross-linker in a concentration exceeding $2 \mathrm{~m} / \mathrm{m} \%$ increased the diameter of the polyvinyl alcohol fibres. When adding $8 \mathrm{~m} / \mathrm{m} \%$ citric acid, an initial diameter of $224 \pm 52 \mathrm{~nm}$ has increased to $269 \pm 109 \mathrm{~nm}$. Furthermore, the distribution also became wider due to the development of bonding points for ester bonds. This process was enhanced by a two-hour heating at $120^{\circ} \mathrm{C}$; thus, resulting in modification of the $\mathrm{OH}$ groups on the surface. The decrease of hydrophilicity was proved by the increase in contact angles. In addition, it was demonstrated that the scaffold structure prepared with this method does not degrade during the 24-120 $\mathrm{h}$ long water treatment.

Keywords: Polyvinyl-alcohol, citric acid, electrospinning, fibre, hydrophilicity, contact angle 